\title{
Kebutuhan Keluarga Pasien diruang Perawatan Intensif
}

\author{
Nurhidayatul Nadya ${ }^{1}$, Gamya Tri Utami ${ }^{2}$, Riri Novayelinda ${ }^{3}$ \\ ${ }^{1,2,3}$ Fakultas Keperawatan, Universitas Riau \\ *Email: nurhidayatulnadya01@gmail.com
}

\begin{abstract}
Background: Patient care in an intensive room affects patients and their family. The impacts experienced by the family are both in physical and psychological aspects. The psychological impact may get higher if the family's needs in the room are not obtained. The study aims to determine the needs of the patient's family in the intensive room. Methods:The design of this research is systematic review. There are some tools used to find related articles to the 2016-2020 period such as Google Scholar, Scient Direct, and PubMed. Results: The search result to obtained 8 articles that met the inclusion criteria. It can be seen that countries in Southeast Asia, Central Asia, and South America share a similar trend which is prioritizing assurance and information needs. The rest of them such as support and comfort are assumed less important although in some articles the order is different. Sociodemography aspects (gender, age, educational level, and spirituality) also influence the priority needs of the family. Conclusion: Even they have different cultural, but the need of family in intensive room have same priority. It's need for assurance.
\end{abstract}

Keywords: family, intensive room, patient's family needs

\section{PENDAHULUAN}

Intensive Care Unit (ICU) merupakan bagian ruangan dirumah sakit yang merawat pasien dengan penyakit trauma, atau komplikasi yang mengancam jiwa. Pasien di ruang intensif memerlukan alat-alat medis guna memperoleh dukungan hidup dan fungsi-fungsi organ vital (Fontaine, Gallo, Hudak, \& Morton, 2012). Jumlah pasien yang dirawat di ICU cukup tinggi. Marshall et al., (2016) mengatakan pasien di Amerika Serikat sebanyak 4 juta orang pertahunnya, sedangkan di Jerman sebanyak 100.000 orang. Pada tahun 2019 pasien yang mendapatkan perawatan intensif di RSUD Arifin Achmad cukup banyak yaitu 1232 orang. Pasien yang dirawat di ICU sebanyak 477 orang, di CVCU 444 orang dan yang dirawat di PICU 311 orang (Rekam Medik RSUD Arifin Achmad, 2019).

Perawatan di ruang intensif bukan hanya berdampak kepada pasien, tetapi juga pada keluarga yaitu dampak fisik diantaranya kelelahan, gangguan tidur dan kesehatan. Dampak psikologis yakni gangguan psikologis seperti cemas, depresi dan Post Traumatic Stress Disorder (PTSD) (Jr \& Douglas, 2010). Hasil penelitian Kristiani \& Dini, (2017) memaparkan tingkat kecemasan pada keluarga dalam kategori sedang (40\%). Menurut Jacob et al., (2016) keluarga yang menunggu pasien di ICU mengalami masalah psikologis seperti stress akut, stress pasca trauma, kecemasan dan depresi.

Masalah psikologis tersebut akan semakin tinggi jika kebutuhan keluarga tidak terpenuhi (Hickman \& Douglas, 2010). Kebutuhan tersebut terdiri dari jaminan, informasi, kedekatan, kenyamanan, serta dukungan. Keluarga memperoleh jaminan bahwa pasien menerima perawatan dan pelayanan terbaik. Kebutuhan informasi terkait kondisi pasien dibutuhkan oleh keluarga guna membantu membuat keputusan yang tepat. Kedekatan keluarga menyebabkan 
pasien nyaman, karena keluarga ikut serta dalam merawat pasien, kenyamanan dibutuhkan karena merupakan salah satu bagian kebutuhan dasar manusia. Kebutuhan dukungan terhadap keluarga juga dibutuhkan karena bisa membantu kondisi keluarga lebih baik (Burn, 2014).

Pemenuhan kebutuhan keluarga diruang intensif salah satunya dipengaruhi oleh aspek sosiokultural. Budaya umumnya mencakup ritual, harapan, hubungan, demografi dan pendidikan (Sinaulan, 2012). Pada umumnya di Indonesia kebutuhan yang paling penting ialah dari dimensi jaminan. Kondisi ini sesuai dengan penelitian yang dilakukan oleh Sulistiyani, (2019) yang menjabarkan bahwa kebutuhan yang paling penting yaitu jaminan sebanyak 46 orang, kemudian informasi sebanyak 39 orang, kedekatan sebanyak 22 orang, dukungan 29 orang dan kenyamanan sebanyak 24 orang. Tujuan penelitian ini yaitu untuk mengetahui aspek kebutuhan keluarga yang paling penting berdasarkan sosiokultural.

\section{METODE PENELITIAN}

Penelitian deskripif dengan metode systematic review. Data yang digunakan yaitu data sekunder berupa hasil-hasil penelitian yang telah diterbitkan dalam jurnal online nasional dan internasional. Peneliti mencari artikel didata base internet menggunakan Semantic schoolar, scient direct dan PubMed. Pencarian artikel memakai keyword "Need of family members AND "intensive care unit", "family need" AND "in intensive care unit". Kriteria inklusi artikel yang direview artikel yang berkaitan dengan kebutuhan keluarga diruang intensif, rentang waktu penerbitan artikel yaitu 5 tahun (2016-2020) agar memperoleh informasi terbaru, artikel dalam Bahasa Indonesia dan Bahasa Inggris, artikel dalam bentuk original artikel dan full text. Artikel dapat diakses tanpa berbayar. Alur telaah artikel dalam systematic review ini dilakukan sesuai gambar 1.

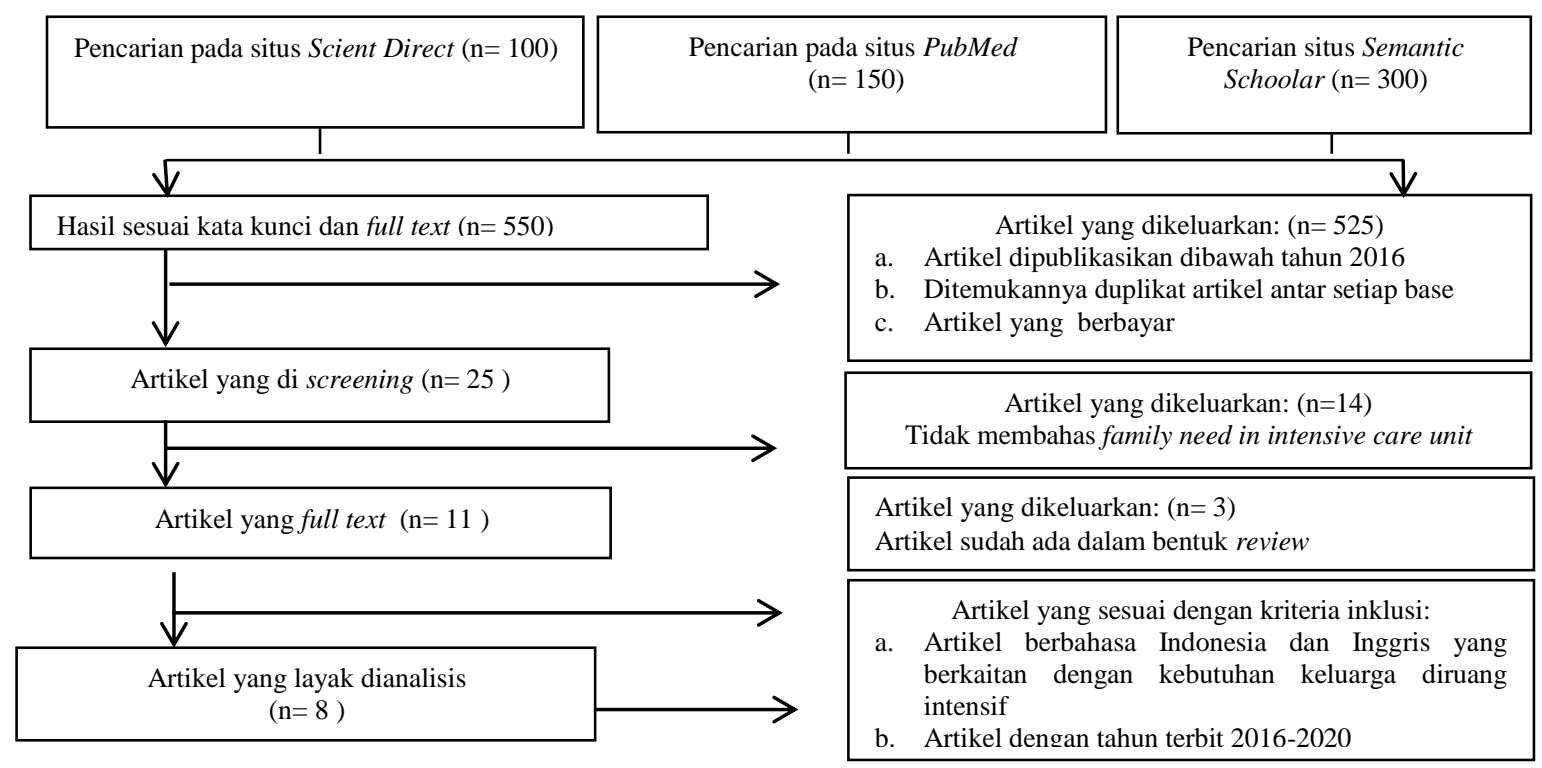

Gambar 1. Tahap Systematic Review 
HASIL PENELITIAN

Tabel 1. Daftar Systematic Review Jurnal

\begin{tabular}{|c|c|c|c|c|c|}
\hline Judul & $\begin{array}{l}\text { Nama } \\
\text { Peneliti \& } \\
\text { Tahun }\end{array}$ & $\begin{array}{c}\text { Tujuan } \\
\text { Penelitian }\end{array}$ & $\begin{array}{c}\text { Metode } \\
\text { penelitian }\end{array}$ & $\begin{array}{c}\text { Sampel } \\
\text { Penelitian }\end{array}$ & $\begin{array}{c}\text { Hasil } \\
\text { penelitian }\end{array}$ \\
\hline $\begin{array}{l}\text { Family } \\
\text { Needs of } \\
\text { Critically } \\
\text { Ill Patients } \\
\text { in Central } \\
\text { Jordan: A } \\
\text { Family } \\
\text { Perspective } \\
\text { ISSN : } \\
2642-1747\end{array}$ & $\begin{array}{l}\text { Almagharb } \\
\text { eh, } \\
\text { Alhassan, } \\
\text { Motlaq \& } \\
\text { Almagarbe } \\
\text { h (2019) }\end{array}$ & $\begin{array}{l}\text { Untuk } \\
\text { menggambark } \\
\text { an persepsi } \\
\text { keluarga } \\
\text { terhadap } \\
\text { kebutuhan } \\
\text { keluarga } \\
\text { diruang } \\
\text { intensif dan } \\
\text { membandingk } \\
\text { an kebutuhan } \\
\text { berdasarkan } \\
\text { demografi } \\
\text { anggota } \\
\text { keluarga }\end{array}$ & $\begin{array}{l}\text { Deskriptif } \\
\text { komparatif } \\
\text { Instrumen: } \\
\text { CCFNI }\end{array}$ & $\begin{array}{l}227 \text { anggota } \\
\text { keluarga } \\
\text { Teknik } \\
\text { pengambilan } \\
\text { sampel: } \\
\text { Teknik } \\
\text { convenience } \\
\text { sampel }\end{array}$ & $\begin{array}{l}\text { Persepsi } \\
\text { keluarga } \\
\text { tentang } \\
\text { urutan } \\
\text { kebutuhan } \\
\text { dari sangat } \\
\text { penting } \\
\text { sampai } \\
\text { kurang } \\
\text { penting } \\
\text { yaitu: } \\
\text { 1. Jaminan: } \\
\overline{\mathrm{x}}=3,47, \\
\text { SD: } 1,77 \\
\text { 2. Informasi } \\
\text { : } \mathrm{x}=3,39 \text {, } \\
\text { SD: } 1,64 \\
\text { 3. Kedekata } \\
\text { n: } \quad \overline{\mathrm{x}}= \\
3,24, \\
\text { SD: } 3,24 \\
\text { 4. Kenyama } \\
\text { nan: } \\
\overline{\mathrm{x}}=2,59 \text {, } \\
\text { SD: } 1,89 \\
\text { 5. Dukunga } \\
\mathrm{n}: \\
\overline{\mathrm{x}}=2,36 \text {, } \\
\text { SD: } 3,08\end{array}$ \\
\hline $\begin{array}{l}\text { The needs } \\
\text { of family } \\
\text { members of } \\
\text { patients } \\
\text { admitted to } \\
\text { the } \\
\text { intensive } \\
\text { care unit }\end{array}$ & $\begin{array}{l}\text { Alsharari } \\
\text { (2019) }\end{array}$ & $\begin{array}{l}\text { Untuk } \\
\text { mengidentifika } \\
\text { si kebutuhan } \\
\text { yang paling } \\
\text { penting dari } \\
\text { keluarga yang } \\
\text { dirawat di ICU } \\
\text { dan } \\
\text { menentukan } \\
\text { hubungan } \\
\text { dengan } \\
\text { karakteristik } \\
\text { sosiodemograf } \\
\text { i mereka. }\end{array}$ & $\begin{array}{l}\text { Cross } \\
\text { sectional } \\
\text { Instrumen: } \\
\text { CCFNI }\end{array}$ & $\begin{array}{l}233 \text { anggota } \\
\text { keluarga yang } \\
\text { menunggu } \\
\text { diruang } \\
\text { intensif dari } \\
\text { bulan April - } \\
\text { Agustus } 2017 \\
\text { Teknik } \\
\text { pengambilan } \\
\text { sampel: } \\
\text { Teknik } \\
\text { convenience } \\
\text { sampel }\end{array}$ & $\begin{array}{l}\text { Urutan } \\
\text { kebutuhan } \\
\text { keluarga dari } \\
\text { yang paling } \\
\text { penting } \\
\text { ialah: } \\
\text { 1. Jaminan: } \\
\overline{\mathrm{x}}=3,62 \text {, } \\
\text { SD: } 0,44 \\
\text { 2. Informas } \\
\text { i: } \quad \overline{\mathrm{x}}= \\
\text { 3,47, } \\
\text { SD: } 0,59 \\
\text { 3. Kedekata }\end{array}$ \\
\hline
\end{tabular}




\begin{tabular}{|c|c|c|c|c|c|}
\hline $\begin{array}{l}\text { Keb } \\
\text { Kel } \\
\text { pasi } \\
\text { diun } \\
\text { pera } \\
\text { intel }\end{array}$ & $\begin{array}{l}\text { Atika \& } \\
\text { Halimuddi } \\
(2018)\end{array}$ & $\begin{array}{l}\text { Untuk } \\
\text { mengetahui } \\
\text { kebutuhan } \\
\text { keluarga yang } \\
\text { menunggu } \\
\text { diruang } \\
\text { intensif rumah } \\
\text { sakit umum } \\
\text { daerah dr. } \\
\text { Zainoel Abidin } \\
\text { Banda Aceh. }\end{array}$ & $\begin{array}{l}\text { Deskriptif } \\
\text { eksploratif } \\
\text { dengan } \\
\text { pendekatan } \\
\text { cross } \\
\text { sectional } \\
\text { Instrumen: } \\
\text { CCFNI }\end{array}$ & $\begin{array}{l}104 \text { orang } \\
\text { keluarga } \\
\text { pasien diruang } \\
\text { intensif } \\
\text { Teknik } \\
\text { pengambilan } \\
\text { sampel: } \\
\text { Teknik } \\
\text { convenience } \\
\text { sampel }\end{array}$ & $\begin{array}{l}\text { Keluarga } \\
\text { menyatakan } \\
\text { urutan } \\
\text { kebutuhan } \\
\text { dari yang } \\
\text { paling } \\
\text { penting } \\
\text { untuk } \\
\text { dipenuhi } \\
\text { yaitu: } \\
\text { 1. Jaminan: } \\
\overline{\mathrm{x}}=3,72, \\
\text { SD: } 0,07 \\
\text { 2. Informas } \\
\text { i: } \overline{\mathrm{x}}= \\
3,18, \\
\text { SD: } 0,22 \\
\text { 3. Kedekata } \\
\text { n: } \overline{\mathrm{x}}= \\
3,10, \\
\text { SD: } 0,34 \\
\text { 4. Kenyama } \\
\text { nan: } \\
\overline{\mathrm{x}}= \\
\text { 3,06, } \\
\text { SD: } 0,40 \\
\text { 5. Dukunga } \\
\text { n : } \overline{\mathrm{x}}= \\
2,78, \\
\text { SD: } 0,30\end{array}$ \\
\hline $\begin{array}{l}\text { Kebutuhan } \\
\text { Keluarga } \\
\text { saat Anak } \\
\text { dirawat di } \\
\text { Pediatric } \\
\text { Intensive }\end{array}$ & $\begin{array}{l}\text { Apriyanti } \\
\& \\
\text { Adawiyah } \\
(2018)\end{array}$ & $\begin{array}{l}\text { Untuk } \\
\text { membandingk } \\
\text { an peresepsi } \\
\text { perawat PICU } \\
\text { dengan } \\
\text { keluarga }\end{array}$ & $\begin{array}{l}\text { Mix method } \\
\text { dengan } \\
\text { pendekatan } \\
\text { kuantitatif: } \\
\text { cross } \\
\text { sectional dan }\end{array}$ & $\begin{array}{lr}51 & \text { resonden } \\
\text { yang } & \text { terdiri } \\
\text { dari } & 30 \\
\text { perawat dan } \\
\text { 21 keluarga. }\end{array}$ & $\begin{array}{l}\text { Urutan } \\
\text { prioritas } \\
\text { kebutuhan } \\
\text { keluarga dari } \\
\text { paling } \\
\text { penting }\end{array}$ \\
\hline
\end{tabular}

n: $\quad \overline{\mathrm{x}}=$ 3,34 ,

SD: 0,44

4. Kenyama nan:

$\overline{\mathrm{x}}=$ 3,01,

SD: 0,72

5. Dukunga n: $\quad \bar{x}=$ 2,91, SD: 0,6 


Care Unit
(PICU):
Sudut
Pabndang
Keluaarga
dan
Perawat.

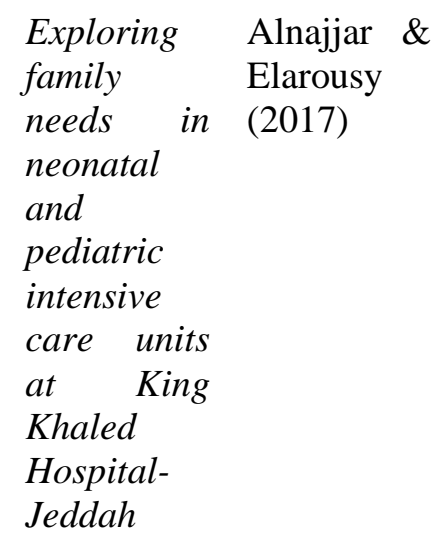

pendekatan
kualitatif
Instrumen:
CCFNI

sampai

prioritas

kebutuhan

keluarga dari

anak yang

dirawat

diruang rawat

intensif

kurang penting:

1. Jaminan: $\overline{\mathrm{x}}=3,75$, SD: 0,11

2. Informasi : $\overline{\mathrm{x}}=$ 3,54,

SD: 0,25

3. Kedekata n: $\overline{\mathrm{x}}=$ 3,37, SD: 0,29

4. Kenyama nan: $\overline{\mathrm{x}}=$ 3,14 ,

SD: 0,45

5. Dukunga $\mathrm{n}$ : $\overline{\mathrm{x}}=2,87$, SD: 0,56

\begin{tabular}{|c|c|c|}
\hline Untuk & Deskriptif & 29 orang \\
\hline $\begin{array}{l}\text { mengeksploras } \\
\text { i } \quad \text { persepsi }\end{array}$ & eksploratif & $\begin{array}{l}\text { dokter, } 54 \\
\text { orang perawat }\end{array}$ \\
\hline perawat, & Instrumen: & dan 18 oran \\
\hline dokter & CCFNI & keluarga ya \\
\hline $\begin{array}{l}\text { orang } \\
\text { tentang }\end{array}$ & & $\begin{array}{l}\text { menunggu } \\
\text { diruang }\end{array}$ \\
\hline kebutuhan & & intensif \\
\hline keluarga & & \\
\hline unit perawatan & & Teknik \\
\hline kritis & & pengambilan \\
\hline Rumah sakit & & sampel: \\
\hline King Khaled & & Teknik \\
\hline di Jeddah & & $\begin{array}{l}\text { convenience } \\
\text { sampel }\end{array}$ \\
\hline
\end{tabular}

Keluarga mengurutkan kebutuhan dari rata-rata yang tertinggi yaitu:

1. Jaminan: $\overline{\mathrm{x}}=3,8$

2. Informas i: $\bar{x}=3,5$

3. Kedekata n: $\quad \overline{\mathrm{x}}=$ 3,4

4. Kenyama nan: $\bar{x}=3,3$

5. Dukunga n: $\quad \bar{x}=$ 2,9 


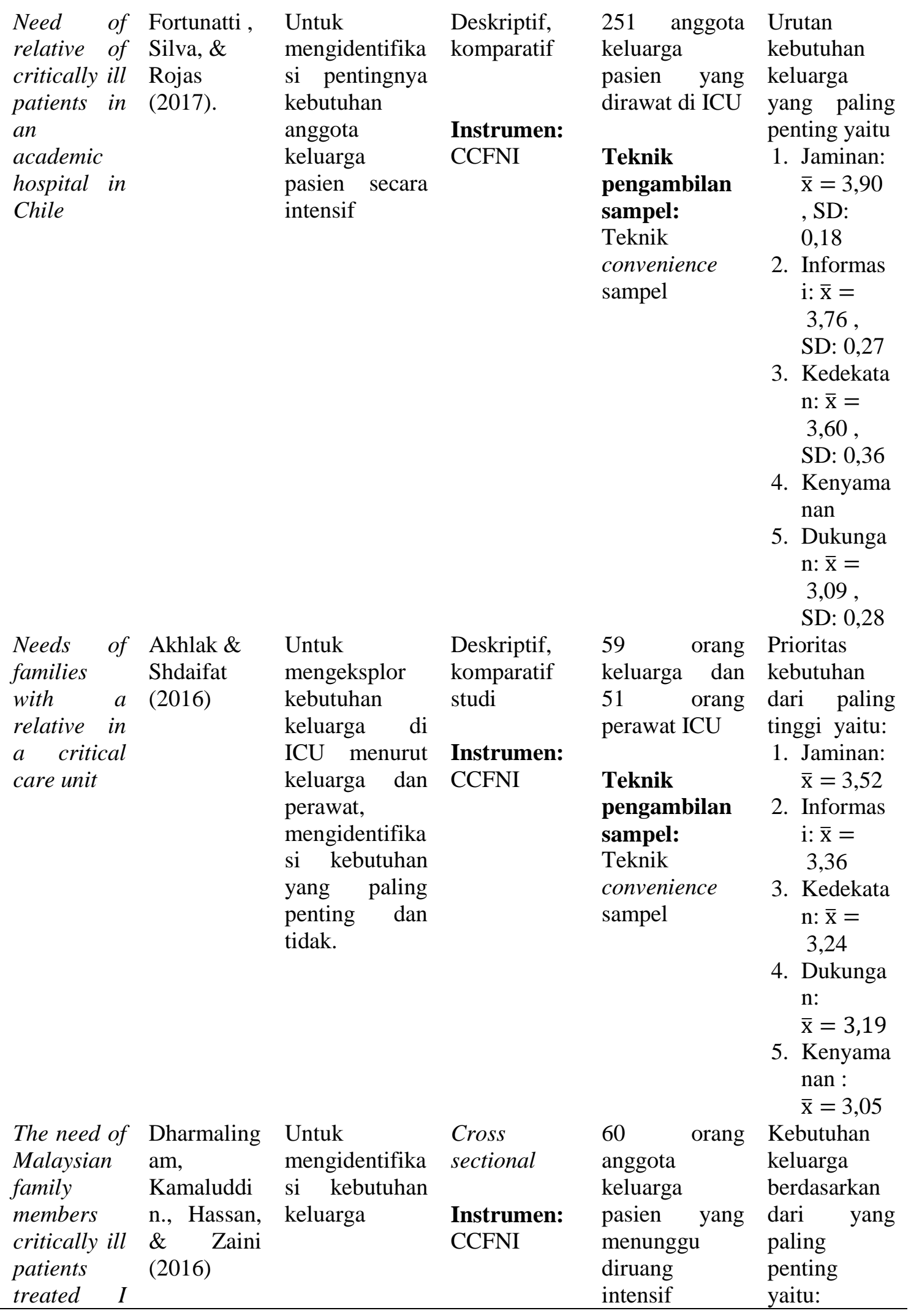


Intensive

Care Unit,

hospital

Universiti

Sains

Malaysia

\section{Teknik pengambilan sampel: \\ Teknik convenience sampel}

1. Jaminan:

$\overline{\mathrm{x}}=3,69$

0,34

2. Informas

i: $\quad \overline{\mathrm{x}}=$

3,59,

SD: 0,37

3. Kedekata $\mathrm{n}: \quad \overline{\mathrm{x}}=$ 3,21

SD: 0,53

4. Kenyama nan:

$\overline{\mathrm{x}}=3,16$

, SD:

0,49

5. Dukunga

$\mathrm{n}: \quad \overline{\mathrm{x}}=$

3,01,

SD: 0,58

\section{PEMBAHASAN}

Tabel 1 menunjukkan review dari artikel yang memenuhi kriteria inklusi dan terdiri dari metode serta tempat penelitian yang berbeda-beda. Dua dari delapan artikel mengunakan desain penelitian deskriptif komparatif studi yang dilakukan oleh Fortunatti, Silva, Rojas, \& Munoz, (2017) dan Almagharbeh, Alhassan, Motlaq, \& Taher, (2019). Tiga artikel menggunakan metode deskriptif crossectional (Alsharari, 2019; Atika \& Hallimuddin, 2018; Dharmalingam, Kamaluddin, \& Hassan, 2017). Satu artikel menggunakan metode deskriptif eksploratif komparatif (Akhlak \& Shdaifat, 2016), satu artikel menggunakan metode deskriptif eksploratif (Alnajjar \& Elarousy, 2017) dan satu artikel menggunakan mixmethod (Apriyanti \& Adawiyah, 2018).

Tempat penelitian dari artikel juga berbeda. Fortunatti, Silva, Rojas, \& Munoz, (2017) mengambil data penelitian di Amerika Selatan tepatnya di Chile. Artikel lainnya berlokasi di Asia Tenggara tepatnya di Indonesia (Apriyanti \& Adawiyah, 2018; Atika \& Hallimuddin, 2018) dan Malaysia (Akhlak \& Shdaifat, 2016; Dharmalingam et al., 2017), serta di Asia Tengah tepatnya di Arab Saudi (Almagharbeh et al., 2019; Alnajjar \& Elarousy, 2017; Alsharari, 2019).

Semua artikel menggunakan kuesioner CCFNI. Negara bagian Asia Tengah dan Amerika Selatan tetap menggunakan 45 butir pernyataan kuesioner CCFNI walaupun sudah dilakukannya uji valid, karena sesuai dengan budaya (Almagharbeh et al., 2019; Alnajjar \& Elarousy, 2017; Alsharari, 2019; P Fortunatti et al., 2017). Hal ini berbeda dengan Asia Tenggara setelah dilakukan uji valid jumlah pernyataanya berkurang, penelitian di Malaysia menggunakan 35 pernyataan yang valid dan sesuai dengan budaya (Akhlak \& Shdaifat, 2016), sedangkan penelitian di 
Indonesia berkurang menjadi 36 pernyataan.

Semua artikel menjelaskan kebutuhan yang paling penting yaitu jaminan. Hal ini sesuai dengan penelitian Bandari, (2015) yang menyatakan kebutuhan jaminan paling penting. Jaminan merupakan hak yang harus diterima keluarga. Bentuk kebutuhan jaminan berupa mengetahui perawatan yang diterima pasien, adanya harapan tentang kesembuhan, dan terjawabnya pertanyaan secara jujur. Terpenuhinya kebutuhan jaminan akan meningkatkan kepercayaan diri dan keluarga merasa aman (Blom, Gustavsson, \& Johansson, 2013; Burn, 2014; Noome, Dijkstra, \& Leeuwen, 2016). Semua artikel menyatakan urutan kebutuhan kedua yang penting yaitu kebutuhan informasi. Hal ini sesuai dengan penelitian Hendrawati et al, (2018) yang menyatakan kebutuhan yang terpenting setelah jaminan yaitu kebutuhan informasi. Informasi tersebut berupa perkembangan pasien, mengetahui hasil pemeriksaan pasien, dan informasi mengenai peraturan di ruang ICU. Informasi ini berguna untuk membuat keputusan bagi keluarga dan mengurangi kecemasan (Urden, Linda, Kathleen, Stacy, Mary, \& Logh, 2010; Beer \& Brysiewicz, 2016; Farahani, Gaeeni, Mohammadi, \& Seyedfatemi, 2014).

Kebutuhan selanjutnya yaitu kedekatan. Keluarga sangat butuh berada disamping pasien. Kebutuhan ini bisa diperoleh bila keluarga dapat menjenguk pasien di ruang ICU secara rutin, berkomunikasi mengenai kondisi pasien dengan perawat yang sama setiap hari, membantu merawat fisik dan mental pasien (Burn, 2014). Kedekatan ini bisa membantu keluarga melakukan perawatan, dan ketika melakukan hal itu keluarga merasa dibutuhkan, meminimalisirkan kecemasan, kekhawatiran dan mencegah terjadinya stress (Knutsson \& Bergbom, 2016; Rusdianti, 2019).

Semua artikel menunjukkan dua kebutuhan yang dianggap kurang penting yaitu kebutuhan dukungan dan kenyamanan. Tujuh dari delapan artikel menyatakan kebutuhan akan dukungan merupakan kebutuhan yang kurang penting. Penelitian ini berbeda dengan Hendrawati et al., (2018) yang menyatakan kebutuhan dukungan sebagai kebutuhan yang agak penting, dikarenakan karakteristik responden yang berbudaya timur lebih mengutamakan persaudaraan sehingga membutuhkan dukungan dari keluarga, kerabat, dan teman.

Satu penelitian lainnya mengatakan kebutuhan yang kurang penting yaitu kebutuhan kenyamanan. Hal ini serupa dengan penelitian Hendrawati et al., (2018) yang menyatakan kebutuhan kenyamanan termasuk kebutuhan kurang penting. Hal ini dikarenakan keluarga lebih mengutamakan kondisi pasien, sehingga mengesampingkan kebutuhan diri sendiri. Ada beberapa item kebutuhan kenyamanan yang penting menurut keluarga seperti adanya tempat duduk dan toilet. Kenyamanan ini sebagai dasar keluarga dalam memenuhi kebutuhan sendiri seperti kebutuhan fisik, sosial dan lain lain (Ahmad, 2019).

Kebutuhan keluarga ini dipengaruhi oleh budaya. Hal ini sesuai dengan penelitian Fortunatti, (2014) yang menyatakan prioritas kebutuhan tergantung pada budaya, keyakinan atau nilai keluarga. Budaya di Indonesia, Malaysia dan Arab Saudi memiliki kesamaan prioritas kebutuhan jaminan yaitu pasien mendapatkan perawatan yang 
terbaik. Budaya di Amerika Selatan tepatnya Chile memiliki prioritas kebutuhan jaminan yang berbeda yaitu kebutuhan mengenai jawaban jujur untuk setiap pertanyaan yang diajukan keluarga (Fortunatti, Silva, Rojas, \& Munoz, 2017).

Keluarga di Asia menyatakan kebutuhan jaminan yang paling penting ialah pasien mendapatkan perawatan terbaik. Kebutuhan ini menjadi kebutuhan yang paling penting karena keluarga merasa ragu, cemas dan takut akan kondisi pasien. Kondisi ini menyebabkan keluarga melakukan segala cara agar pasien mendapatkan perawatan yang terbaik termasuk tetap mempertahankan alat-alat bantu hidup hingga pasien benarbenar tidak dapat ditolong lagi . Kondisi keluarga ini dapat diperbaiki dengan memberitahukan penyakit yang dialami pasien, prognosis kedepannya, tindakan yang dilakukan serta memberikan sikap empati kepada keluarga (Hendrawati et al., 2018).

Budaya di Amerika Selatan tepatnya Chile memiliki prioritas kebutuhan jaminan yang berbeda yaitu kebutuhan mengenai jawaban jujur atau kepastian untuk setiap pertanyaan yang diajukan keluarga (Fortunatti, Silva, Rojas, \& Munoz, 2017). Hal ini didukung oleh penelitian Obringer et al (2012) keluarga di Amerika lebih mementingkan kebutuhan agar pertanyaan dijawab dengan jujur. Alasan dibutuhkannya kebutuhan ini karenakan pengalaman keluarga sebelumnya tidak mendapatkan informasi yang lengkap sehingga membuat keraguan bagi keluarga (Ahmad, 2019). Keluarga juga mendapatkan informasi dengan bahasa yang sulit untuk dimengerti sehingga keluarga meminta saat pemberian informasi dibutuhkan juga informasi dalam bentuk tulisan atau brosur sehingga mudah diingat (Jouffroy et al., 2013)

Prioritas kebutuhan keluarga bukan hanya dipengaruhi oleh budaya akan tetapi juga dipengaruhi faktor sosiodemografi. Enam dari delapan artikel menjelaskan mayoritas keluarga diruang intensif berjenis kelamin perempuan (Akhlak \& Shdaifat, 2016; Apriyanti \& Adawiyah, 2018; Atika \& Hallimuddin, 2018; Dharmalingam, Kamaluddin, \& Hassan, 2017; P Fortunatti, Silva, Rojas, \& Munoz, 2017). Artikel lainnya menyatakan jenis kelamin laki-laki yang dominan diruang intensif. Penelitian Bandari, (2015) yang menyatakan keluarga laki-laki mementingkan kebutuhan terkait mendapatkan perawatan yang terbaik, dan dukungan finansial sebagai kebutuhan yang tidak penting. Keluarga perempuan memprioritaskan jujur saat menjawab pertanyaan dan kenyamanan ruang tunggu sebagai kebutuhan yang tidak penting.

Usia keluarga juga mempengaruhi prioritas kebutuhan. Semua artikel menunjukkan keluarga diruang intensif umumnya pada kategori dewasa muda dengan umur lebih dari 30 tahun (Erikson dalam Upton, 2012). Kondisi ini membuat keluarga lebih membutuhkan kebutuhan dukungan dan kenyamanan, karena lebih penting untuk memenuhi kebutuhan dasar seperti akses ke toilet, telepon dan ketersediaan makanan.

Faktor sosiodemografi selanjutnya yaitu tingkat pendidikan. Mayoritas tingkat pendidikan keluarga SMA dan sarjana. Keluarga yang memiliki tingkat pendidikan tinggi menganggap kebutuhan akan informasi kurang penting untuk dijelaskan secara detail karena sudah memahami dengan pemahaman mereka (Fortunatti, Silva, Rojas, \& Munoz, 2017). 
Keluarga yang memiliki pendidikan tinggi lebih menuntut kebutuhan jaminan yang tinggi dari pada keluarga yang berpendidikan rendah (Dharmalingam et al., 2017). Spiritualitas juga mempengaruhi kebutuhan keluarga. Keluarga yang menganut agama Islam menyatakan lebih kuat akan ikatan sosial, emosional dan harapan terhadap kesembuhan pasien sehingga keluarga mengatakan tidak masalah dengan waktu jenguk pasien yang terbatas (Alnajjar \& Elarousy, 2017).

\section{KESIMPULAN DAN SARAN}

Hasil review dari kedelapan jurnal menghasilkan dimensi yang sama sebagai prioritas kebutuhan yaitu aspek jaminan. Budaya negara bagian Asia Tenggara, Asia Tengah dan Amerika Selatan menyatakan kebutuhan yang paling penting yaitu kebutuhan jaminan, akan tetapi aspek jaminan yang paling dibutuhkan berbeda. Pentingnya mengetahui apa saja kebutuhan keluarga diruang perawatan intensif sehingga membantu tenaga kesehatan dalam melakukan asuhan keperawatan yang holistik dan komprehensif. Pengetahuan terhadap aspek sosiokultural dan sosiodemografi yang mempengaruhi prioritas kebutuhan, penting untuk diketahui petugas kesehatan sehingga bisa membantu dalam memenuhi kebutuhan keluarga.

\section{DAFTAR RUJUKAN}

Ahmad, I. M. (2019).Comparison between nurses and families opinion about priorities of immediate patient's familyneeds,9(1),113121.https://doi.o rg/10.5430/jnep.v9n1p113

Akhlak, S., \& Shdaifat, E. (2016). Needs of families with a relative in a critical care unit. Malaysian Journal of Public Health Medicin, 16(3), 7581.Retrievedfromhttps://www.res eacrchgate.net/publication/3017652 68

Almagharbeh, W. T., Alhassan, M. A., Motlaq, M. Al, \& Taher, R. N. E. (2019). Family Needs of Critically Ill Patients in Central Jordan: A Family Perspective.American Journal of Biomedical Science \& Research., 217221.https://doi.org/10.34297/AJB SR.2019.01.000546

Alnajjar,H.,\&Elarousy,W.(2017).Explorin $\mathrm{g}$ family needs in neonatal and pediatric intensive care units at King Khaled Hospital-Jeddah.ClinMed Invest,2(4),177.https://doi.org/10.157 61/CMI.1000145

Alsharari, A. . (2019). The needs of family members of patients admitted to the intensive care unit. Dove Medical Press Journal, 465-473. Retrieved from https://pubmed.ncbi.nlm.nih.gov/310 40650

Apriyanti, E., \& Adawiyah, R. (2018). Kebutuhan keluarga saat anak dirawat di paediatric intensive care unit ( picu ): sudut pandang Pendahuluan Metode. Jurnal Keperawatan Indonesia, 21(3), 159168.https://doi.org/10.7454/jki.v21i3. 777

Atika, \& Hallimuddin. (2018). Kebutuhan keluarga pasien di unit perawatan intensif, III (3). 
Bandari, R. (2015). Information and support needs of adult family members of patients in intensive care units : an Iranian perspective. https://doi.org/10.1177/1744987115 591868

Beer, J. De, \& Brysiewicz, P. (2016). The needs of family members of intensive care unit patients : A grounded theory study. Southern African Journal of Critical Care, 32(2), 44-49. https://doi.org/10.7196/SAJCC.2016. v32i 2.298

Blom, H., Gustavsson, C., \& Johansson, A. (2013). Participation and support in intensive care as experienced by close relatives of patients - A phenomenological study. Intensive \& Critical Care Nursing, 29(1), 1-8. https://doi.org/10.1016/j.iccn.2012.0 4.002

Burns, S.M., (2014). AACN Essential Of Critical Care Nursing. Edisi 3. A. American : The McGraw-Hill Edition

Dharmalingam, T. K., Kamaluddin, M. R., \& Hassan, S. K. (2017). The Needs of Malaysian Family Members of Critically Ill Patients Treated in Intensive Care Unit , Hospital Universiti Sains Malaysia. Malaysian Journal of Medicine and Health Sciences, (June 2016). Retrieved from.https://www.researchgate.net/p ublication/311695456

Farahani, M. A., Gaeeni, M., Mohammadi, N., \& Seyedfatemi, N. (2014). Journal of Medical Ethics and History of Medicine Giving information to family members of patients in the intensive care unit: Iranian nurses ' ethical approaches. Journal of Medical Ethics and History of Medicine., 1-7.Retrieved from.https:/pubmed.ncbi.nlm.nih.gov /pmc/articles/PMC4263385/

Fontaine, D.K., Gallo, M.B., Hudak, C.M., \& Morton, P.G. (2012). Critical care nursing. Jakarta : EGC.

Fortunatti, P. (2014). Most Important Needs Of Family Members Of Critical Patients In Light Of The Critical Care Family Needs Inventory. Investigacion \& Educacion En Enfermeria, 32(2), 306-316. Retrieved from https://pubmed.ncbi.nlm.nih.gov/252 30040/

Fortunatti, P., Silva, R., Rojas, M. ., \& Munoz, Y. . (2017). Needs of relatives of critically ill patients in an academic hospital in Chile $\leftleftarrows$. https://doi.org/10.1016/j.enfie.2017.0 9.002

Hendrawati, S., Fatimah, S., Yuyun, S., Fitri, R., Mardhiyah, A., \& Nurhidayah, I. (2018). Kebutuhan orang tua dalam perawatan bayi sakit kritis di neonatal intensive care unit ( nicu ) Needs of Parents in Critically Ill Infants Care in the Neonatal Intensive Care Unit ( NICU ), 9, 4357. Retrieved from https://jkp.fkep.unpad.ac.id/index.ph $\mathrm{p} / \mathrm{jkp} / \mathrm{article} / \mathrm{view} / 453$

Hickman,R.L., \& Douglas, S. . (2010). Impact of Chronic Critical Illness on 
the Psychological Outcomes of Family Members. Aacn Advanced Critical Care, 21(1), 80-91. Retrieved from https://pubmed.ncbi.nhlm.nih.gov/20 $118707 /$

Jacob, B. M., Horton, C., Rance-ashley, S., Field, T., Patterson, R., Johnson, C., Frobos, C. (2016). Needs of patients' family members in an intensive care unit with continuous visitation. American Journal Of Critical Care, 25(2), 118-125. Retrieved from https://pubmed.ncbi.nlm.nih.gov/269 32913/

Jouffroy, R., Lamhaut, L., Cremniter, D., An, K., Carli, P., \& Vivien, B. (2013). Family's and/or relatives expectationts concerning a patient emergently hospitalized into an intensive care unit after out-ofhospital medical care of by samu team, 32, 94-97. https://doi.org/10.1016/j.annfar.2012. 11.010

Knutsson, S., \& Bergbom, I. (2016). Children' S Thoughts And Feelings Related To Visiting Critically Ill Relatives In An Adult ICU: A qualitative study. Intensive \& Critical Care Nursing, 32, 33-41. https://doi.org/10.1016/j.iccn.2015.0 7.007

Kristiani, R. B., \& Dini, A. N. (2017). Komunikasi Terapeutik Dengan Tingkat Kecemasan Keluarga Pasien Di Intensive Care Unit ( icu ) rs adi husada kapasari surabaya, 3(2), 7175 . Retrieved from http://adihusada.ac.id/jurnal/index.ph $\mathrm{p} / \mathrm{AHNJ} /$ article/view/101

Marshall, J. C., Bosco, L., Mdem, N. K. A., Connolly, B., Diaz, J. V, Dorman, T., ... Janice, Z. (2016). NU AC PT. Journal of Critical Care. https://doi.org/10.1016/j.jcrc.2016.07 .015

Ningsih,S.S. (2017). Pengalaman Keluarga Menghadapi Hospitalisasi Pasien Kritis Di Ruang ICU RSUP Dr Kariadi Semarang. Retrieved from https://eprints.unip.ac.id

Noome, M., Dijkstra, B. M., \& Leeuwen, E. Van. (2016). Exploring family experiences of nursing aspects of end-of-life care in the ICU: A. Intensive \& Critical Care Nursing, 33, 56-64. https://doi.org/10.1016/j.iccn.2015.1 2.004

Obringer, K., \& Booker, H.C. (2012). Need Of Adult Family Members Of Intensive Care Unit Patient. Journal of Clinical Nursing. Retrieved from: https://pubmed.ncbi.nlm.nih.gov/224 04287/

Rekam Medik RSUD arifin Achmad. (2019). Laporan Tahunan Pasien Diruang Intensif Pekanbaru: RSUD Arifin Achmad

Rusdianti, A. (2019). Kebutuhan Keluarga Pasien yang Dirawat Intensive Care Unit (ICU): Literature Review, 9(6), 1-7. Retrieved from http://2trik.jurnalelektronik.com/ 
100 Jurnal Keperawatan Global, Volume 5, No 2, Desember 2020, hlm 56-117

Sinaulan, J.H., (2012). Dimensi Sosio Kultural Dalam Promosi

Kesehatan. Jurnal Sosilogi Islam

Sulistiyani., A. (2019). Gambaran

Kebutuhan Keluarga Pasien

Perawatan Intensif di RS PTPN 10

Jember. Retrieved from

http://repository.unej.ac.id/handle/12

$3456789 /$

Upton. (2012). Psikologi. Jakarta:

Erlangga

Urden., Linda, D., Kathleen, M., Stacy., Mary, E., \& Lough. (2010). Critical care nursing: Diagnosis and Management. Sixth Edition. Diperoleh tanggal 10 Agustus 2020 dari

https//www.elsevier.com/books/ 